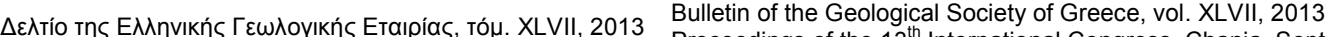
Proceedings of the $13^{\text {th }}$ International Congress, Chania, Sept.

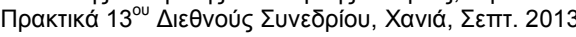
2013

\title{
HYDROGEOPHYSICAL EXPLORATION FOR ESTIMATING GROUNDWATER RESERVOIRS AREAS IN SOUTHERN RHODES THROUGH ERT (ELECTRICAL RESISTIVITY TOMOGRAPHY) METHOD
}

\author{
Karmis P. ${ }^{1}$, Giannoulopoulos P. $^{2}$, Sofos F. ${ }^{1}$ and Lappas $I^{2}$ \\ ${ }^{I}$ National Centre of Sustainable Development - Institute of Geology and Mineral Exploration, \\ Sector of Basic and Applied Geology, Department of Geophysics, 13677 Acharnai, Athens, Greece \\ ${ }^{2}$ National Centre of Sustainable Development - Institute of Geology and Mineral Exploration, \\ Sector of Water Resources and Environment, Department of Hydrogeology, 13677 Acharnai, \\ Athens, Greece
}

\begin{abstract}
The present study deals with the groundwater investigation of hydrogeological conditions of Southern Rhodes, in the search for additional groundwater supplies to support the water needs of the area. An extensive Hydrogeological - Geophysical research was conducted, aimed to identify exploitable groundwater zones. This geophysical survey was carried out along alluvial basins, looking for more permeable geological formations within the sequence of the Neogene and Quarternary deposits. The use of a high resolution geophysical method (ERT) was selected for targeting the shallow geological structures and hydrostratigraphy. Thirteen ERT sections of total length of approximately $34000 \mathrm{~m}$ were measured, laid out primarily at the south eastern part of the island. The geophysical survey revealed that alluvial sediments have an average thickness of about $30 \mathrm{~m}$ while nearby the coastal zone increase locally up to $50 \mathrm{~m}$. The hydrostratigraphical structure is characterized by three distinct sections, the overlying alluvial deposits, the intermediate clay-marls and the underlying coarse formations. Moreover, almost all fault zones which are reflected in the surface geological map are revealed in greater depths. Result of vertical tectonic movements is the uplift of geological formations with increased resistivity. Finally, the target areas were selected based on hydrogeological criteria and specifically taking into account the increased possibility of groundwater reservoirs within the alluvial aquifer.

Key words: Groundwater supplies, exploitable groundwater zones, high resolution geophysical method, hydrostratigraphy.
\end{abstract}

\section{Пєрí $\eta \psi \eta$}

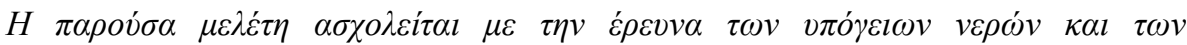

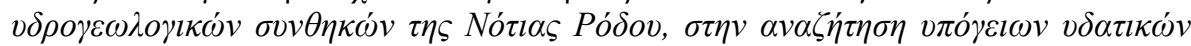

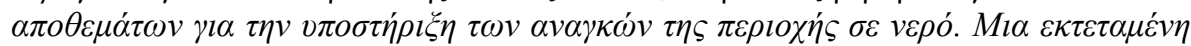

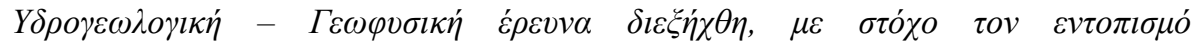

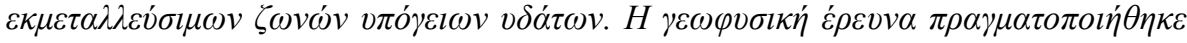

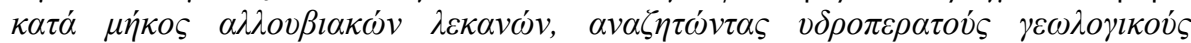

$\underline{\text { XLVII, No } 3-1118}$ 


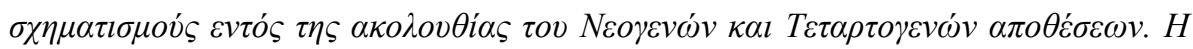

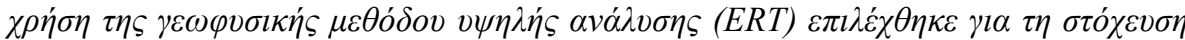

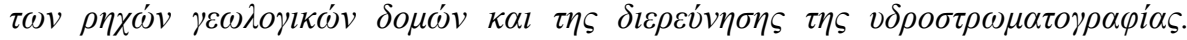

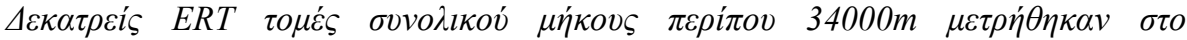

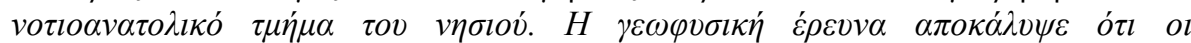

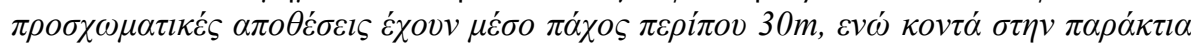

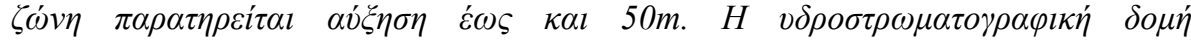

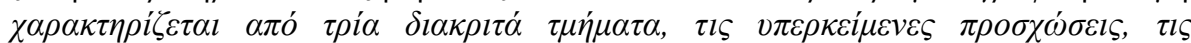

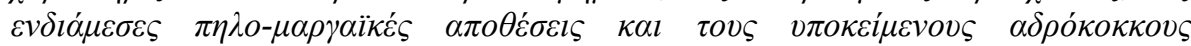

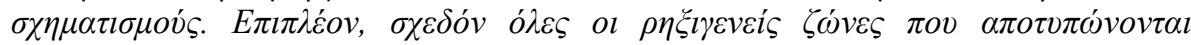

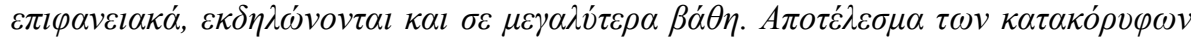

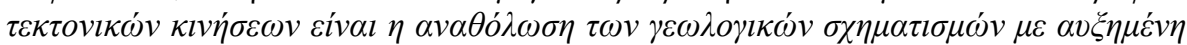

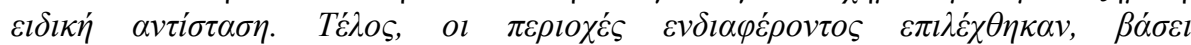

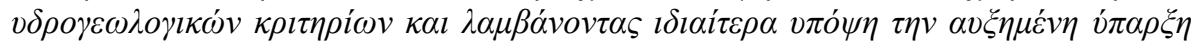

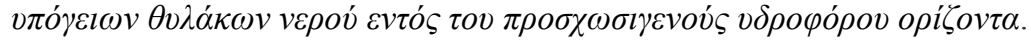

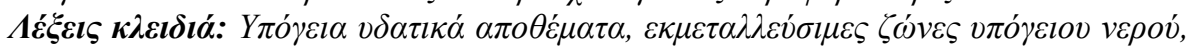

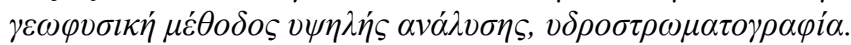

\section{Introduction}

The present study investigates the hydrogeological conditions of Southern Rhodes with regards to the search for additional groundwater resources for supporting the water needs of the study area. Taking into account the acute water supply problem during the summer season, due to the population rise, the extended drought as well the quantitative and qualitative aquifers degradation because of the excessive pumping, the need for finding groundwater permeable areas becomes crucial. Given the available data from previous geological and hydrogeological studies taken place by the Institute of Geology and Mineral Exploration, an extensive Hydrogeological - Geophysical campaign was conducted, aimed to identify exploitable groundwater zones.

\section{Methodology}

The hydrogeophysical exploration aims to quantify the subsurface hydrogeological parameters based on experience in oil and mineral investigation. Yet in hydrogeological applications the contrast between the target's physical properties and environment's is small making the geophysical response obscure. For that reason, the use of high resolution geophysical methods is necessary in order to determine the nature and geometry of the shallow geological structures. The geophysical survey was conducted along the alluvial basins of Asklipio - Gennadi, Vati, Kolonitis and Lachania, exploring systematically the potential groundwater ability of the geological formations.

The choice of the most suitable geophysical method depends on the geological - hydrogeological settings, the penetration depth and the topographic relief. On sedimentary basins, the DC Vertical Electrical Sounding (VES) method (Koefoed, 1979) provides information of the geological stratigraphy and identifies the existence or not of the potential groundwater zones. In cases, however, of lateral geological variations and complex topographic relief, the above method has limited reliability and effectiveness, taking into consideration the need of large electrode arrays in the field (Rubin et al., 2005). The growth of geophysical data inversion techniques along with the development of hardware has resulted to the emerging of subsurface imaging methods, such as the Electrical Resistivity Tomography (ERT) as one of the most effective methods (Dahlin, 2001), combining advantages such as: a) imaging reliability of the actual distribution of the subsurface resistivity, b) high definition of the two-dimensional geoelectrical structure and c) topographic correction removing the effect of topographic relief (Kirsch, 2005, Rubin et al., 2005).

$\underline{\text { XLVII, No } 3 \text { - } 1119}$ 
In case of Southern Rhodes the Syscal Pro (Iris) system (Kim, 2009) was used with a multiprobe array of 48 electrodes of $20 \mathrm{~m}$ dipole length, with the penetration depth reaching $200 \mathrm{~m}$. This was considered satisfactory taking into account the seawater intrusion and the relatively mild topographic relief of the study area. With the constant movement of the array and a $50 \%$ overlap of the electrodes spread, long lines of length up to $4800 \mathrm{~m}$ were covered. Thirteen (13) ERT sections with total length of $34000 \mathrm{~m}$ were surveyed, focused on the Eastern part of the study area. The selection of target areas was based on hydrogeological criteria and taking into account the increased possibility of groundwater reservoirs within the alluvial aquifer.

\section{Geological, Tectonics and Hydrogeological Settings}

\subsection{Geology}

The Rhodes island's stratigraphy is characterized by the presence of Neogene sediments and the formations of the Ionian geotectonic zone (Figure 1). Specifically it consists of:

- Plio - Pleistocene deposits: consisted of talus and land deposits. They mostly appear at the Southern part of the island between the hilly area of Katavia and Prasonissi over Sgourou formations. The latter consists of porous limestones and greenish - grey marls with sand and gravels over Levantine deposits, which are consisted of fluvial conglomerates, sands and silty marls.

- Oligocene - Miocene deposits: comprised of Mesanagros sandstone, Agios Minas marls and Kortiatis conglomerates derived from ophiolites, limestones and radiolarites as well Thari formation consisting of ophiolithic, carbon and silicate conglomerates. This sedimentary sequence lies unconformably between the overlying Levantinian deposits and the underlying flysch of Ionian geotectonic zone.

- Ionian geotectonic zone: Katavia flysch, Hocene limestones, marly and silicate limestones (upper Jurassic - upper Cretaceous) are included.

- Pindos geotectonic zone: consisted of Malona limestones with silica and radiolarites, Elafokampos silicate, well-bedded dolomitic limestones, Kopria diavases - radiolarites and Ophiolites (Triassic - Jurassic).

- Parnassos geotectonic zone: Archipolis flysch (Paleocene - Hocene), Salakos limestones and Koumouli limestones (Triassic - Hocene) are included.

- Gavrovo - Tripolis geotectonic zone: consisted of thick-bedded, crystallic Lindos limestones (Cretaceous) of maximum thickness $450 \mathrm{~m}$.

\subsection{Tectonics}

The study area is characterized by the post alpine sediments monoclinic structure. Katavia flysch is the geological bedrock, overlaid by Kortiatis conglomerates, Mesanagros sandstones, Agios Minas marls, Levantinian sediments and gray - greenish Sgourou formations. Stratigraphic unconformities exist almost to all above formations' contacts. At the central and eastern part of the study area the formations have monoclinic structure with a Southeastern dip, while at the western part of Apolakia a West - Northwestern dip prevails. The folding tectonics is almost completely absent however the presence of faulty structure is significant with faults intersecting both alpine and post - alpine formations: the prevailing fault systems are of Southwest - Northeast and Northwest - Southeast direction, perpendicular to each other. 


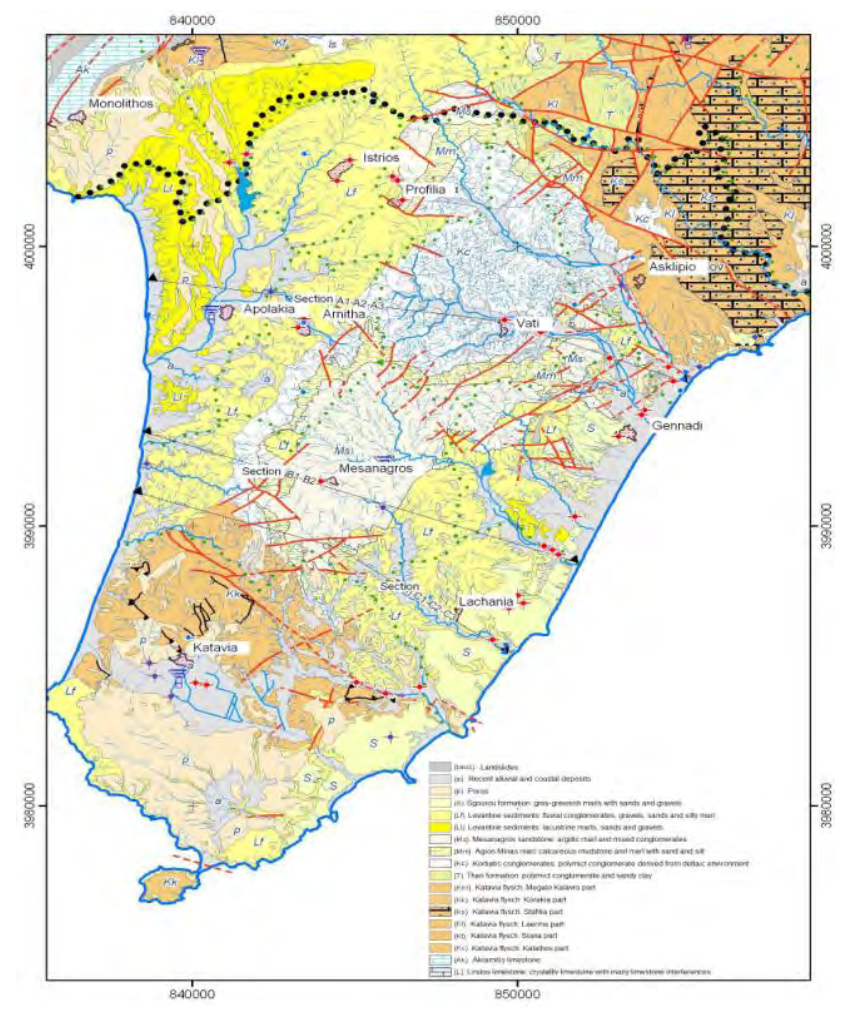

Figure 1 - Geological map of Southern Rhodes (Mutti et al., 1965 with modifications).

\subsection{Hydrogeology}

The aquifers directly depend on the hydrogeological behavior and the tectonics of geological formations, according to which they are divided into impermeable, semi-permeable and permeable ones (Giannoulopoulos and Lappas, 2008, 2010).

- Impermeable formations: Katavia flysch, clay phase of Levantinian sediments and Agios Minas marls are included.

- Semipermeable formations: Mesanagros sandstones, Levantinian sediments, Sgourou formation and Kortiatis conglomerates are included. Drilled boreholes to the above mentioned formations yield $5-15 \mathrm{~m}^{3} / \mathrm{h}$.

- Permeable formations: Alluvial and fluvial deposits of the coastal zones and within the valleys which are included from Asklipio to Katavia. Drilled boreholes to these sediments yield over $60 \mathrm{~m}^{3} / \mathrm{h}$. At Katavia alluvial aquifer boreholes yield between $10-20 \mathrm{~m}^{3} / \mathrm{h}$.

The region's aquifers are the followings (Figure 2):

- Alluvial aquifer of Asklipio - Gennadi - Lachania: consisted of coarse sediments which are derived from the underlying Kortiatis conglomerates and Levantine sediments. Drilled boreholes to these sediments exceed yields locally over $60 \mathrm{~m}^{3} / \mathrm{h}$.

- Alluvial aquifer of Apolakkia: developed in the western part and lithologically consists of erosion materials derived from Levantine sediments which are finer than those in the eastern part. That is the reason why boreholes yield less than those in the eastern zone and range from 10 to $20 \mathrm{~m}^{3} / \mathrm{h}$. 
- Alluvial aquifer of Katavia: developed in the southern part of the island, surrounded mostly by flysch and consisted of fine thin sediments, while the boreholes yields do not exceed $20 \mathrm{~m}^{3} / \mathrm{h}$.

- Aquifers of Levantine sediments: two separate aquifers are identified, the one of the eastern part and that of the western. In the eastern part, the aquifer is developed at the hilly region of Gennadi - Lachania, while at the western one the aquifer covers the hilly regions of Arnitha, Apolakia and Istrios. Boreholes yields range from 5 to over $30 \mathrm{~m}^{3} / \mathrm{h}$ and depend directly on sediments's lithological in-homogeneities.

Mesanagros sandstone has flyschoid texture and is not expected to host remarkable groundwater resources. A borehole drilled at depth greater than $150 \mathrm{~m}$ is reported to yield only $10 \mathrm{~m}^{3} / \mathrm{h}$. Kortiatis conglomerates are coarse derived from gravels and sands with relatively limited clay phase participation. Vati's borehole yields almost $10 \mathrm{~m}^{3} / \mathrm{h}$, while it is estimated that the formation may yield significantly higher groundwater quantities taking into account its lithological texture.
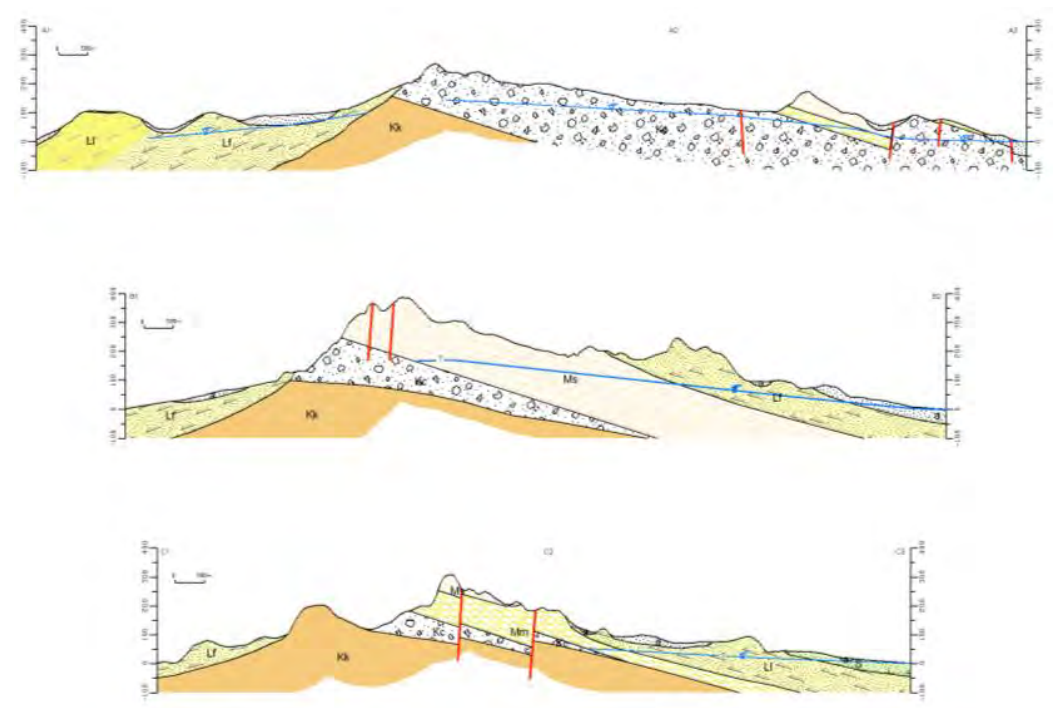

Figure 2 - Schematic hydrolithological sections (Giannoulopoulos and Lappas, 2008).

\section{Geophysical Investigation, Processing and Interpretation}

The data processing followed the steps: i) measuring the coordinates of the start and end of each line, the intermediate centers of the arrays, as well as the altitude of each electrode through a digital elevation model (DEM), ii) calculation of the Digital elevation model (DEM) of the island with a cell size of $20 \mathrm{~m}$ which was utilized in assigning the actual coordinates of the electrodes, calculating the correct geometrical factors of the array and correcting the topographic relief and iii) inversion of data with an iterative smoothness constrain scheme (DC2Dpro, Kim, 2009). The location of ERT lines is shown in Figure 3.

\subsection{Gennadi Area - Section 1}

The results of the inversion - interpretation are shown in Figure 4. Numbers 1 to 9 correspond to successive spread centers along the line. All sections are plotted from West to East or NW to SE.

Gennadi 1-1: The largest part of the line $(0-1500 \mathrm{~m})$ exhibits surface cover of coarse sediments with resistivity values in the range of $70-200 \Omega . \mu$, thickness of $40-50 \mathrm{~m}$, implying possible association with water reservoir. These sediments are consisted of fluvial conglomerates, gravels 
and sands included in Levantine deposits. Stratigraphically under the conglomerates, conductive clay and marly sediments can be detected which are attributed to Levantine sediments and Agios Minas marls. Also, resistive anomalies possibly associated with conglomerates of Levantine sediments or more likely with the underlying Mesanagros sandstones can be recognized. The ERT image explains the satisfactory yield of G41 and G42 boreholes, which despite their shallow depth they exploit areas with increased thickness of the surface layer of permeable conglomerates.

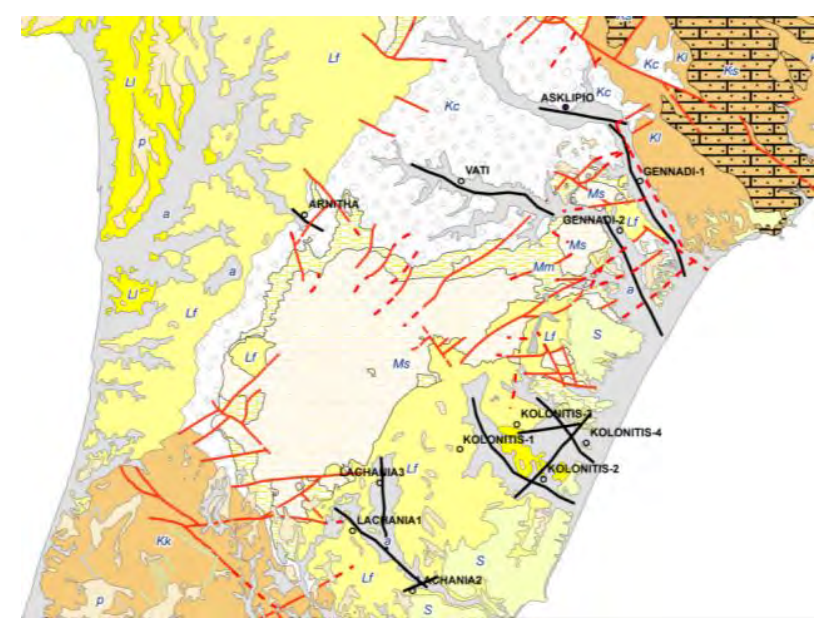

Figure 4 - Location map of ERT lines.

Gennadi 1-2: Tectonic discontinuities are identified mainly within the high resistivity conglomerates or sandstones. The surface layer of coarse sediments is detected in the second half of the line with relatively lower thickness and anomalies that may prove potential groundwater areas.

Gennadi 1-3: The surface layer of coarse sediments reaching $35 \mathrm{~m}$ of thickness is occasionally detected. The conductive layer of clays and marls under the conglomerates is detected while antistatic anomalies are identified at depth, associated with the carbonate parts of Katavia flysch and determined by tectonic discontinuities. The shape of the anomaly and resistivity values of 100

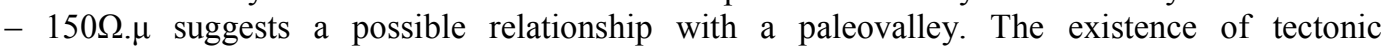
discontinuity within the margins favors the potential permeable formation's supply.

\subsection{Gennadi Area - Section 2}

The top layer of fluvial conglomerates with thickness up to $30 \mathrm{~m}$ is detected, underlain by a conductive layer of fine sediments associated to clays and marls. Resistive anomalies are located below, confined by tectonic discontinuities, possibly associated to permeable carbonate formations. To the South of the spread center 6 the boundaries of seawater intrusion are detected with characteristically very low resistivity values of $2 \Omega . \mu$. At the proximity of the limits of the seawater intrusion in the area, two active boreholes G43 and G106 exist, of very shallow depth (40m) exploiting the surface permeable layer of conglomerates. These boreholes will be most likely contaminated by seawater intrusion at deeper levels and their exploitation should be carefully monitored.

\subsection{Asklipio Area}

The top resistive layer of fluvial layer of conglomerates is clearly seen, with thickness of $30 \mathrm{~m}$, underlain by conductive clay - marly sediments with low resistivity values of $5 \Omega . \mu$. Resistive anomalies are recorded at deeper levels, possibly associated to probable permeable formations, bounded by tectonic discontinuities (Figure 5a).

XLVII, No 3 - 1123 

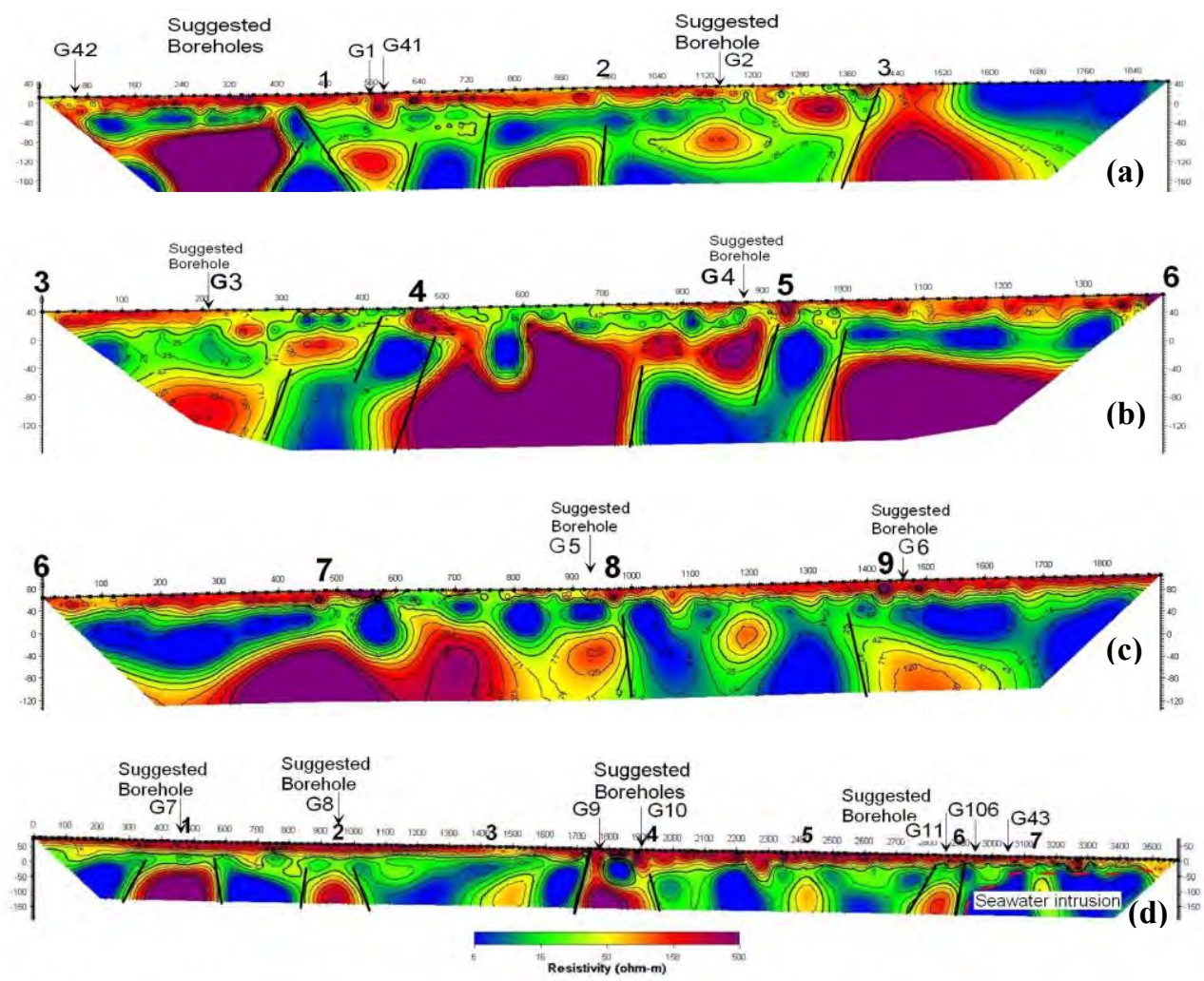

Figure 4 - ERT inversion results along Gennadi lines 1-1 (a), 1-2 (b), 1-3 (c) and line 2 (d).

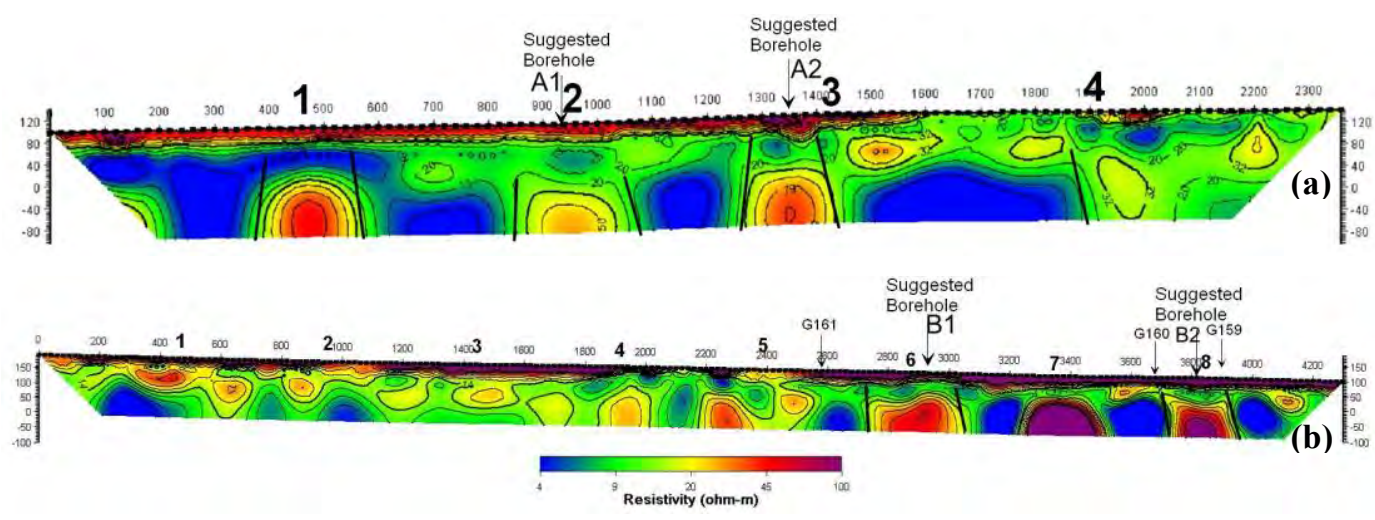

Figure 5 - ERT inversion results along Asklipio (a) and Vati (b) lines.

\subsection{Vati Area}

The surface layer of conglomerates is detected, along the entire length of the line, reaching a maximum thickness of $35 \mathrm{~m}$ at the Eastern part of the section (Figure $5 \mathrm{~b}$ ). This is underlain by conductive clay materials, belonging to Agios Minas marls. The position of three existing boreholes G159, G160 and G161 is drawn on the ERT section and it can be clearly seen that the limited thickness of the conglomerates explains the fact that all three boreholes are dry or yield very small groundwater quantities. 


\subsection{Kolonitis Area}

Line 1: The shallow layer of gravels and sands reaches the thickness of $20 \mathrm{~m}$ (Figure 6a). To the Southeast and between the centers 6 and 8, the layer's thickness increases up to 50m approximately and the nearby boreholes (G45, G171 and G172) exploit this particular layer. Tectonic discontinuities are also identified which delineate the carbonate parts of Levantine sediments. The negative aspect in hydrogeological prospect is that these carbonate formations are surrounded by strongly conductive formation associated to impermeable silty marl, diminishing the groundwater potential of the area. An important point of interest is the extended seawater intrusion reaching up to $1700 \mathrm{~m}$ from the coast so it is assumed there is a serious risk of boreholes contamination. From the above data it is concluded that no borehole drilling can be proposed in this area.

Line 2: In the first $600 \mathrm{~m}$ along the line, the shallow layer of gravels reaching the maximum thickness of $38 \mathrm{~m}$ is recognized (Figure $6 \mathrm{~b}$ ). The conductive layer of silty marl is detected below. Between the stations 700 and 1100 a conductive layer of very low resistivity $(<2 \Omega$. $\mu)$ is identified which is attributed to seawater intrusion. Tectonic discontinuities are also identified at stations 200,400 and 700 . The seawater intrusion as well as the general resistivity image of the line does not justify any borehole target proposal.

Line 3: It is concluded through ERT image that the geological structure is consisted of Levantine sediments with conglomerates, gravels, sands and marls (Figure 6c). At the center of the line a resistive anomaly is recorded with possible association to sandstone. At the Eastern part of the line a shallow layer of conglomerates with underlying marl is also identified.

Line 4: The shallow layer of conglomerates with an average thickness of $15 \mathrm{~m}$ is recognized, underlain by Levantine fine sediments (Figure 6d). Moreover, tectonic discontinuities can be observed. At station 500 the shape of the resistivity image suggests a possible paleovalley bounded by tectonic discontinuities.
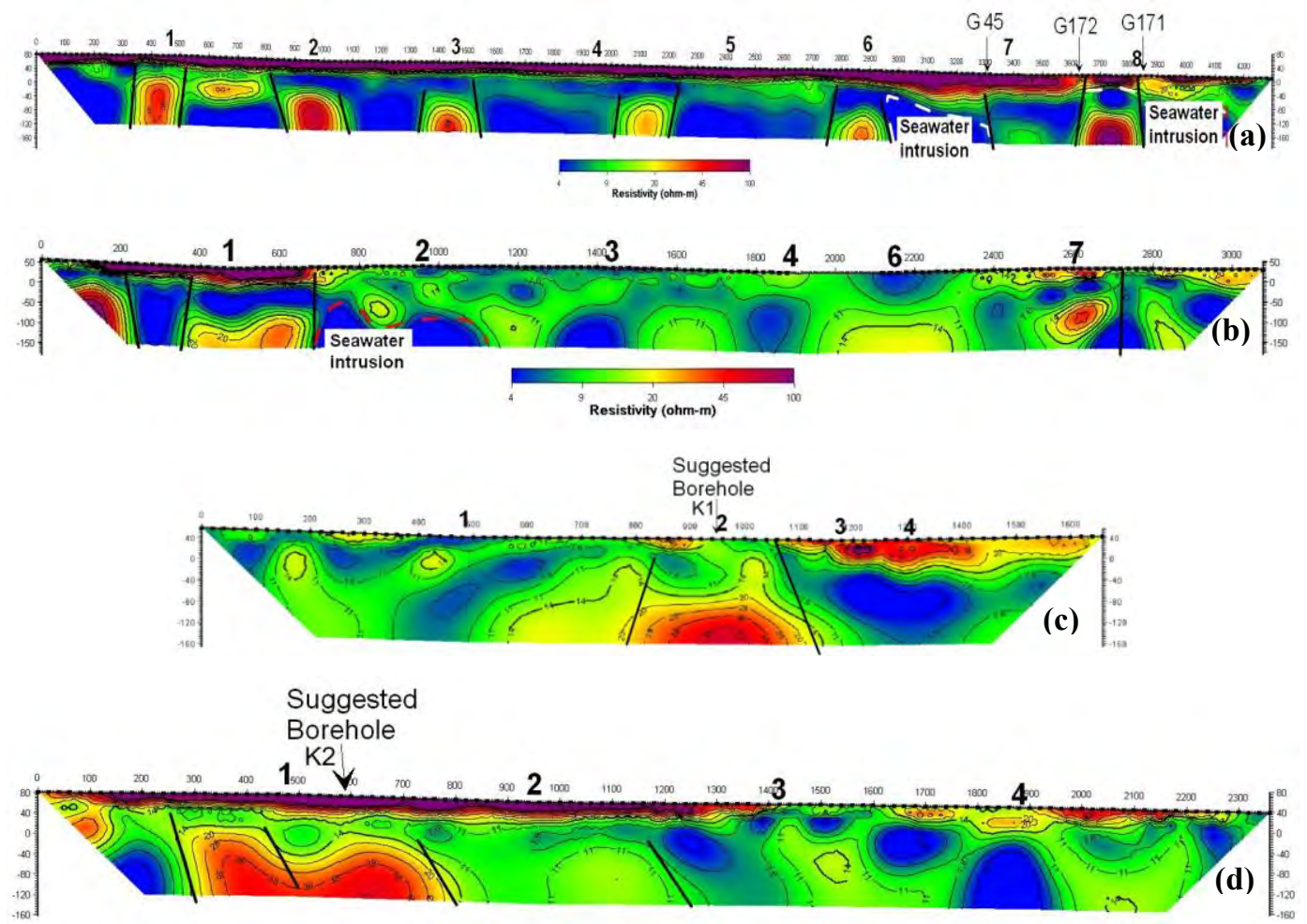

Figure 6 - ERT inversion results along Kolonitis lines 1(a), 2(b), 3(c) and 4 (d).

XLVII, No 3 - 1125 


\subsection{Lachania Area}

Line 1: The line is entirely structured by fine thin sediments, alluvial deposits, sands and marls (Figure 7a).

Line 2: A surface thin layer of conglomerates at the center of the section with a maximum thickness of $20 \mathrm{~m}$ is detected while the underlying one is attributed to marls (Figure $7 \mathrm{~b}$ ). Between the locations 560 and 700 a low resistivity value area is recognized indicating seawater intrusion. The seawater intrusion may be taking place in the first half of the ERT too where the resistivities are also very low.

Line 3: The hydrogeological interest of this line is focused on the first half and especially on the existence of successive tectonic discontinuities limiting the extent of resistive blocks uplifted within a regionally conductive environment of impermeable marls (Figure 7c). These are probably

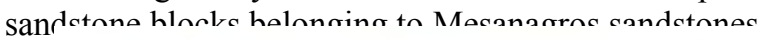
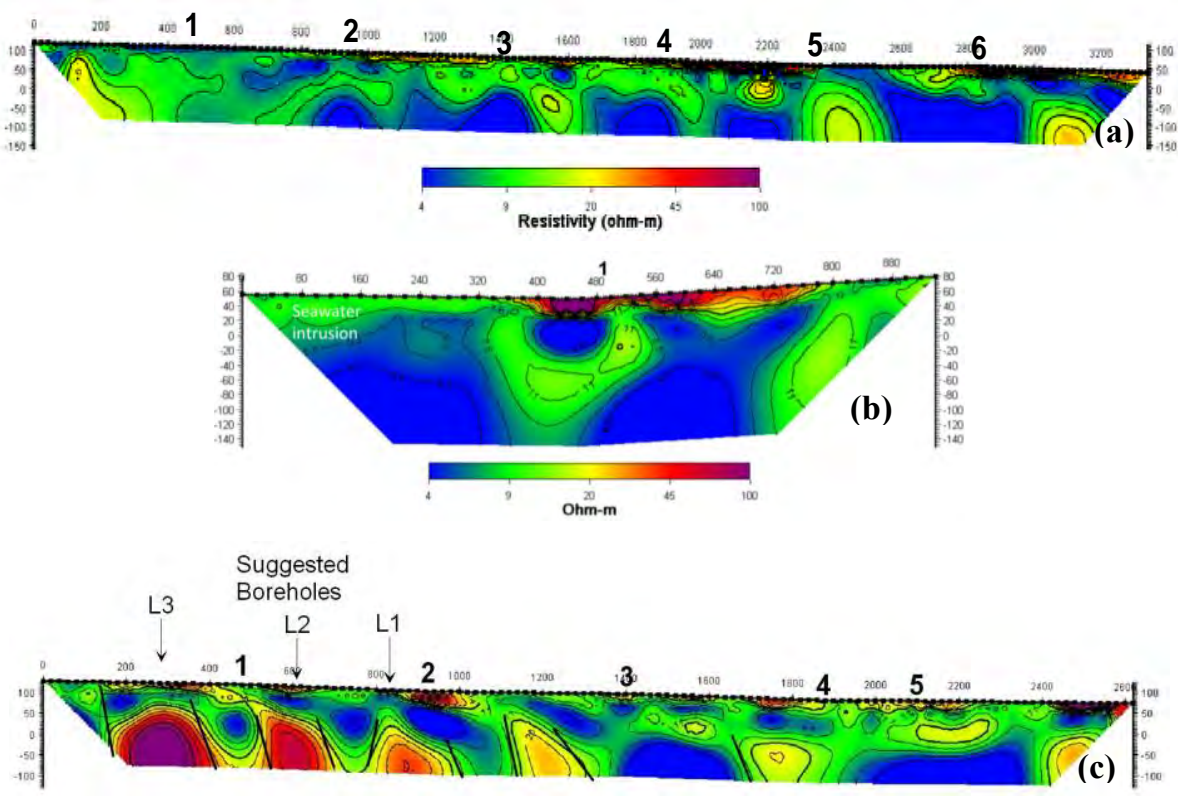

Figure 7 - ERT inversion results along Lachania lines 1(a), 2(b) and 3 (c).

\subsection{Arnitha Area}

The top layer of resistive conglomerates reaching a thickness of $30-35 \mathrm{~m}$ covers the whole extent of the line. This is underlain by marly and clastic parts of Kortiatis conglomerates as well as the Levantine marls. The suggested borehole at station 100 is expected to drill increased thickness of surface conglomerates and a resistive block probably associated to the Kortiatis conglomerates.

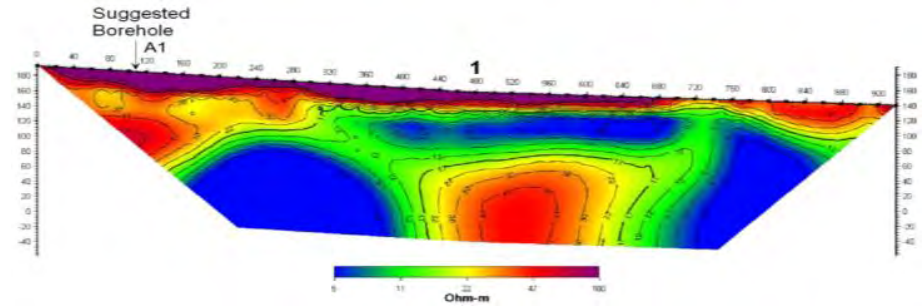

Figure 8 - ERT inversion results along Arnitha line.

$\underline{\text { XLVII, No } 3 \text { - } 1126}$ 


\section{Concluding Remarks}

From the hydrogeophysical survey conducted on the Southern part of Rhodes island, the following conclusions can be drawn:

- The fluvial deposits between Asklipio and Lachania basins have an average thickness of $30 \mathrm{~m}$ which in some places mostly nearby the coastal zone increase locally up to $50 \mathrm{~m}$ forming favorable groundwater conditions.

- The hydrogeological - geophysical structure is characterized by three distinct sections: 1) the overlying alluvial - fluvial deposits, 2) the intermediate clay - marly formations (Agios Minas marls and the clay phase of Levantine sediments) and 3) the underlying coarse formations (Mesanagros sandstone and Kortiatis conglomerates). The groundwater potential of the shallow alluvial aquifer is mainly concentrated near the coastal zone. West from the coastal zone, groundwater is expected in areas with strong lithological inhomogeneities as well as in the vicinity of fracture zones.

- All fracture zones mapped in the area have been detected by the ERT survey along with additional structural discontinuities with no surface expression. From geophysical evidence it is suggested that these structural lines are related to the uplift of resistive geological formations, possibly attributed to Mesanagros sandstones or Kortiatis conglomerates.

- At the area of Gennadi the seawater intrusion has advanced at $800 \mathrm{~m}$ from the coast line and it may affect the existing wells G43 and G106. This problem is more severe at the Kolonitis area, where the seawater intrusion has advanced at $1700 \mathrm{~m}$ from the coastline probably affecting the wells G45, G171 and G172.

- A number of boreholes have been selected for drilling, as shown in Figures 4 to 9 and they are all expected to intersect coarse groundwater permeable formations.

\section{Acknowledgements}

The authors would like to thank the board of the municipality of Southern Rhodes for the hospitality and the unconditional help offered to all phases of the field work for the whole project's accomplishment.

\section{References}

Dahlin T. 2001. The development of DC resistivity imaging techniques, Computers \& Geoscience, 27, (9), 1019-1029.

Giannoulopoulos P. and Lappas I. 2008. Hydrogeological Identification and Mapping of Water Supply Conditions in the Municipality of Southern Rhodes, Rhodes Island, Prefecture of Dodecanese, I.G.M.E., Athens.

Giannoulopoulos P. and Lappas I. 2010. Hydrogeological Study of the Water District of Aegean Islands. Water Resources Assessment, Quality Control and Development Proposals. 3rd Community Support Framework, I.G.M.E., Athens.

Kim Y.H. 2009. DC2Dpro - User's Manual, KIGAM, Daejon, Korea.

Kirsch R.2005. Groundwater Geophysics. Springer, 492 pp.

Koefoed O.1979. Geosounding principles, 1, Resistivity Sounding Measurements. Elsevier, Amsterdam.

Mutti E., Orombelli G. and Pozzi R. 1965. Geological Map of Rhodes Island, University of Milan Italy.

Rubin Y. and Hubbard S. 2005. Hydrogeophysics, Springer, 521 pp. 